\title{
A new representative of the genus Bryocyclops Kiefer, 1927 from a karst cave in north-eastern Thailand (Copepoda, Cyclopoida, Cyclopidae) and comments on the generic affinities
}

\author{
Santi Watiroyram ${ }^{1}$ \\ 1 Division of Biology, Faculty of Science, Nakhon Phanom University, Nakhon Phanom, 48000, Thailand \\ http://zoobank.org/C786D024-63D4-474C-8F54-A9101E246312 \\ Corresponding author: Santi Watiroyram (santi.watiroyram@npu.ac.th)
}

Academic editor: Kay Van Damme • Received 23 March 2020 • Accepted 29 August 2020 • Published 3 February 2021

\begin{abstract}
The seventh Thai species of Bryocyclops Kiefer, 1927 - Bryocyclops jayabhumi sp. nov. - was found in a karst cave in the Chaiyaphum Province of north-eastern Thailand. The new species differs from all previously-known species by the absence of an inner seta on the proximal endopod of the first four swimming legs. Bryocyclops jayabhumi sp. nov. is most similar to B. maholarnensis Watiroyram, Brancelj \& Sanoamuang, 2015 - the monotypic species of Group VII, which was previously described from Thailand. However, the new species differs from B. maholarnensis by having the following characteristics: i) posterior margin of urosomites serrated; ii) anal operculum triangular with acute-tip; iii) P1-P4 Enp-1 without an inner seta; iv) armature on the female P2-P3 Enp-2 and P4 Enp; v) a transformed spine on the male P3 Enp-2. In this study, the generic affinity of the genus Bryocyclops Kiefer, 1927 is discussed and redefined, based on the available literature concerning its principle morphology to fill the present knowledge gap about the characteristics of the genus.
\end{abstract}

\section{Key Words}

cave fauna, epikarst, groundwater, Southeast Asia, Thailand

\section{Introduction}

North-eastern Thailand (locally called 'Isan') is located on the Khorat Plateau and encompasses approximately $200,000 \mathrm{~km}^{2}$ or one-third of the country (Smith and Stokes 1997). Its major geographic features are the plains and mountain ranges along the region's western edge (i.e. Phetchabun Mountain), especially in the Loei, Nong Bua Lam Phu and Chaiyaphum Provinces. Two faunal groups (snails and geckos) have been intensively researched in the caves in this area (Ellis and Pauwells 2012; Pauwels et al. 2014; Tumpeesuwan and Tumpeesuwan 2014; Tanmuangpak 2015), but few studies have focused on aquatic invertebrates, though the region boasts highly diverse, cave-dwelling fauna - especially Copepoda (Watiroyram et al. 2015, 2017). To date, four cave-dwelling copepods have been reported in north-eastern Thailand, including Bryocyclops maholarnensis Watiroyram, Brancelj \& Sanoamuang, 2015; B. muscicola (Menzel, 1926); Elaphoidella bidens decorata (Daday, 1901); and E. namnaoensis Brancelj, Watiroyram \& Sanoamuang, 2010 (Watiroyram et al. 2017; Watiroyram 2018).

The genus has, so far, been divided into seven species groups (I-VII) and four subgenera: Bryocyclops s. str.; Haplocyclops Kiefer, 1952; Palaeocyclops Monchenko, 1972; and Rybocyclops Dussart, 1982. The latter three have been further split into the three different genera (Kiefer 1927; Lindberg 1953, 1956; Monchenko 1972; Dussart 1982; Rocha and Bjornberg 1987; Ranga Reddy and Defaye 2008; Watiroyram et al. 2015; Fiers and Van Damme 2017). Recently, a species of Group II - B. soqotraensis Mirabdullayev, Van Damme \& Dumont, 2002 - was re-evaluated and given to a new genus: Thalamocyclops Fiers \& Van Damme, 2017 (Rocha et al. 1998; Fiers 2002; 
Fiers and Van Damme 2017). In addition, Fiers and Van Damme (2017) note that the species of Groups I, II and VII (Lindberg 1953; Watiroyram et al. 2015) share generic affinities and a common lineage, but species of Group III (B. constrictus Lindberg, 1947; B. travancoricus Lindberg, 1947) and Group IV (B. africanus Kiefer, 1932); Bryocyclops (Palaeocyclops) jankowskajae Monchenko, 1972 present different lineages that are clearly unrelated to Bryocyclops s. str. (Reid and Spooner 1998; Fiers 2012). Based on the available literature and the discovery of the new species described herein, this study discusses and updates the generic affinity of Bryocyclops Kiefer, 1927.

\section{Materials and methods}

\section{Site description}

Chaiyaphum Province sits in the westernmost edge of this plateau, mostly covered by Triassic-Tertiary sedimentary rocks and Permian limestone (Singtuen and Won-In 2018). The Prakai Phet cave of Chaiyaphum Province, located in the Phetchabun Mountain Range, is made of dolomitic limestone karst formed in the Permian Period and it served as a refuge for several Pleistocene mammals (Filoux et al. 2014). This cave is about $1.5 \mathrm{~km}$ long, ending in a 45 $\mathrm{m}$-deep abyss and only $15 \mathrm{~m}$ of the cave's anterior is open to tourists. The present author visited the cave in the rainy season once a year - September and October 2017-2019 - and a single population of the new copepod on the floor and stalagmites, which are formed by dripping water, was collected at about 4-5 $\mathrm{m}$ from the cave's entrance (Fig. 1).

\section{Sampling and specimen preparation}

Samples were collected using a hand net $(60 \mu \mathrm{m})$ from drip pools on the stalagmites and the cave floor and then fixed immediately in ca. $70 \%$ ethanol. Adult animals were picked out and preserved with $70 \%$ ethanol in $1.5 \mathrm{ml}$ microtube. Adult specimens were dissected under an Olympus SZ51 stereomicroscope in a mixture of glycerol and 70\% ethanol (ratio 1:10 v/v). Dissected specimens were mounted in pure glycerol and sealed with transparent nail polish. Permanent slides with dissected animals were examined with an Olympus compound microscope (CX31) at 1000× magnification. Pencil drawings were made with a drawing tube (an Olympus U-Da) mounted on a compound microscope, then the final drawings were scanned for correction in the CORELDRAW 12.0 graphic programme. Specimens for scanning electron microscopy (SEM) were dehydrated in progressive ethanol concentrations $(70 \%, 80 \%$, $90 \%, 95 \%, 100 \%$ and $100 \%$ absolute ethanol) for $15 \mathrm{~min}$ each concentration. Specimens were dried in a critical point dryer using liquid carbon dioxide as the exchange medium. Dried specimens were mounted on stubs using adhesive tape under the stereomicroscope. Specimens were coated with gold in a sputter-coater. The SEM photographs were made using a scanning electron microscope (LEO $1450 \mathrm{VP}$ ).

The morphological terminology follows Huys and Boxshall (1991). Specimens were deposited at the Natural History Museum, London, United Kingdom (NHMUK) and the Nakhon Phanom University, Faculty of Science, Thailand (NPU).
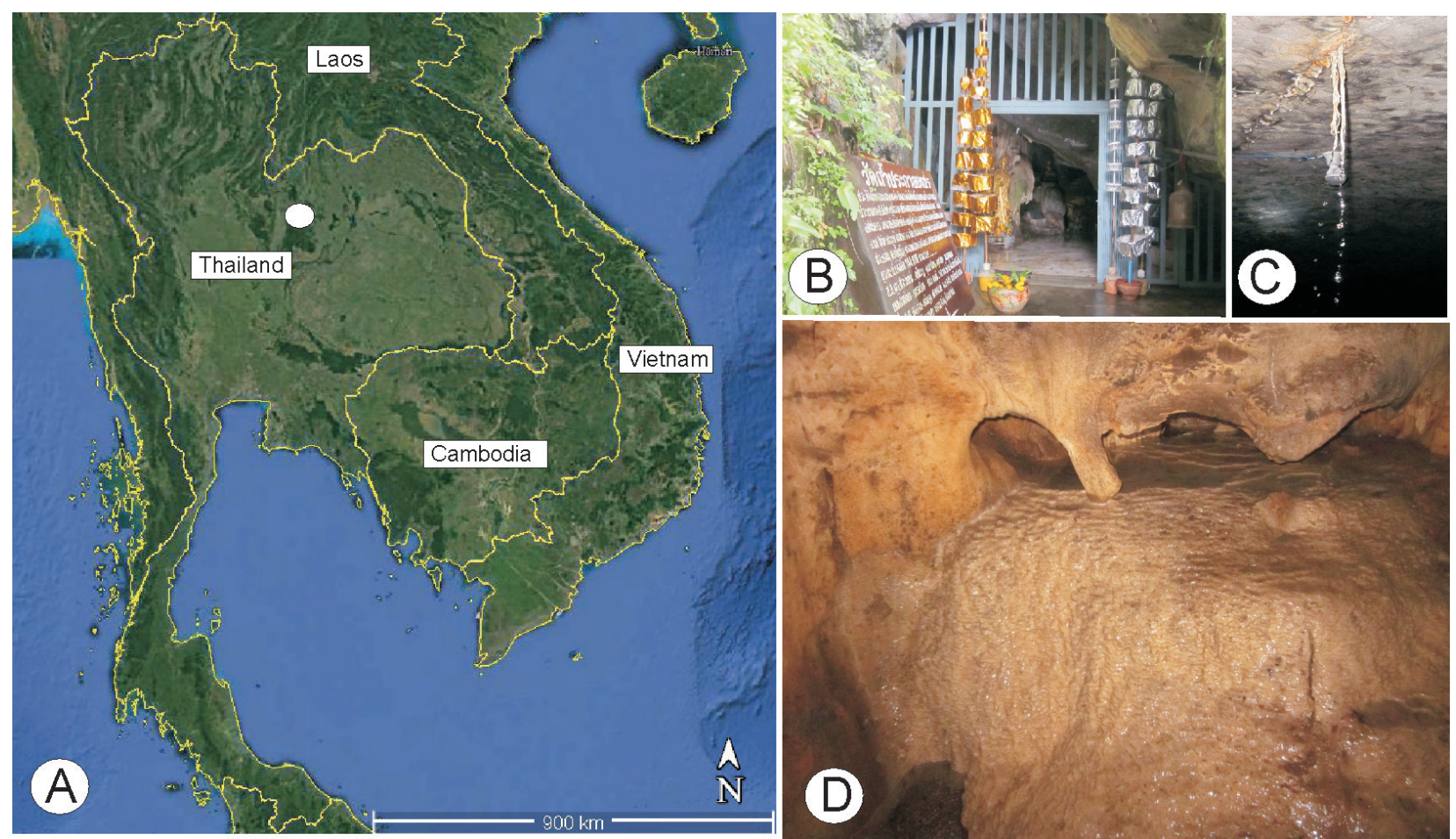

Figure 1. The sampling site and habitat of B. jayabhumi sp. nov.: A. Sampling site indicated with white circle (o); B. The entrance of the cave; C. Dripping water from the plant roots penetrating from the surface; D. pool on stalagmite. 


\section{Abbreviations}

The following abbreviations are used throughout the text and figures:

$\begin{array}{ll}\text { A } & \text { aesthetasc; } \\ \text { Enp } & \text { endopod; } \\ \text { Exp } & \text { exopod; } \\ \text { Exp/Enp-n } & \text { exopodal segment n/endopodal segment n; } \\ \text { P1-P6 } & \text { swimming legs 1-6; } \\ \text { Sp } & \text { spine/spines. }\end{array}$

\section{Taxonomic section}

\section{Order Cyclopoida Rafinesque, 1815 \\ Family Cyclopidae Rafinesque, 1815 Genus Bryocyclops Kiefer, 1927}

\section{Bryocyclops jayabhumi sp. nov.}

http://zoobank.org/8A037BC7-5D7F-4EC3-961B-EA1A6F9897F8 Figs 2-6

Type locality. A rimstone pool that is close to an entrance (see site description) in the Prakai Phet Cave (Fig. 1), Thung Luilai Subdistrict, Khon San District, Chaiyaphum Province, north-eastern Thailand; coordinates of cave entrance: $16^{\circ} 29^{\prime} 03^{\prime \prime} \mathrm{N}, 101^{\circ} 47^{\prime} 05^{\prime \prime} \mathrm{E}$, altitude: $573 \mathrm{~m}$ above sea level.

Material examined. Holotype: one adult female dissected and mounted on one slide (NHMUK 2020.48); allotype: one adult male dissected and mounted on one slide (NHMUK 2020.49); paratypes: one adult female dissected and mounted on one slide (NPU 2020-001), three adult females and three adult males preserved in $70 \%$ ethanol (NHMUK 2020.50-55), three adult females and three adult males preserved in $70 \%$ ethanol (NPU 2020-002). All specimens were collected from the type locality on 9 October 2017 by the author.

Etymology. The species name is taken from the Sanskrit words 'jaya' and 'bhumi', meaning 'land of victory' or 'Chaiyaphum' in Thai, referring to the Chaiyaphum Province, where the new species was collected.

Description. Adult female. Habitus (Fig. 2A) cyclopiform $(n=5)$. Body length, excluding caudal setae, $340 \mu \mathrm{m}$, with prosome/urosome ratio of 1.6. Body surface ornamented with refractile points (not figured). Nauplius eye indiscernible. Prosome with length/width ratio of 1.9. Posterior margins of prosomites with smooth hyaline fringe. Cephalothorax completely fused, with several pairs of sensilla scattered dorsally on surface; pedigers 2-3 with pair of sensilla dorsally; greatest width at anterior part of cephalothorax (Fig. 2B, C). Urosome length $130-151 \mu \mathrm{m}$; length/width ratio of $2.2(\mathrm{n}=5)$. Genital double-somite (Fig. 2C, D) enlarged; anterior slightly wider than posterior; 1.3 times as wide as long (n $=5$ ), with transverse sclerotised suture indicating ancestral segmentation; with pair of dorsal sclerotised rounded structures and P6 dorsolaterally; posterior margin with slightly irregular serrated hyaline fringe. Copulatory pore (Fig. 3I) behind one-half length of segment; copulatory duct narrow, short, strongly sclerotised. Seminal receptacle with anterior expansion at about one-half length of anterior portion; lateral arm narrow, slightly posteriorly curved. Urosomites 3-4 (Fig. 2E, G) shorter than wide, 1.6 times as long as wide $(n=5)$; ornamented with transverse row of shallow pits dorsolaterally; narrow serrated hyaline fringe. Anal somite (Fig. 2E, G) short, 1.6 times as long as wide $(\mathrm{n}=5)$; two dorsal sensilla at base of anal operculum; transverse row of spinules distally on ventral and dorsolateral side. Anal operculum (Fig. 2E) well developed, extended to tip of caudal ramus; triangular, acute tip; free margin smooth. Caudal ramus (Fig. 2E, G) asymmetrically conical, about 1.5 times as long as wide, with dorsal longitudinal keel. Lateral seta (II) bare, slightly shorter than caudal ramus, inserted at one-half of caudal ramus length. Outermost terminal seta (III) bipinnate, longer than caudal ramus, with spinules at insertion point on ventrolateral side. Outer terminal seta (IV) bipinnate, about 4.0 times as long as caudal ramus, with fracture plane. Inner terminal seta (V) bipinnate, about 6.0 times as long as caudal ramus, with fracture plane. Innermost terminal seta (VI) bare; short. Dorsal seta (VII) bipinnate, about 2.0 times as long as caudal ramus, inserted at distal end of longitudinal keel.

Antennule (Fig. 3A). Eleven-segmented, not reaching posterior margin of cephalothorax, ornamented with refractile points. Armature formula as follows: 6.2.5.2.0.2.3.1+A.2.2.6+A; all setae smooth; aesthetascs slender, fused basally with seta as acrotheck.

Antenna (Fig. 3B). Four-segmented, coxobasis with one distomedial seta. Enp-1 unarmed. Enp-2 with five distomedial setae. Enp-3 with seven apical setae, both ornamented with spinular row along lateral margin. All setae smooth.

Mandible (Fig. 3C) with six strongly-chitinised teeth; dorsal seta on gnathobase. Palp reduced to one bare seta.

Maxillule (Fig. 3D) with three strongly-chitinised teeth on precoxal arthrite; four bare setae and one pinnate seta on inner margin. Coxobasis with three bare setae distally. Exp reduced to one bare seta. Enp with three bare setae.

Maxilla (Fig. 3E) with precoxal endite with two pinnate setae. Coxa with two endites: proximal endite with one bare seta; distal endite with two bare setae. Basis with two strong claw-like expansions, bare seta close to its base. Two-segmented Enp: Enp-1 with one bare seta; Enp-2 with three bare setae.

Maxilliped (Fig. 3F). Four-segmented; syncoxa with transverse row of spinules and two pinnate setae. Basis and Enp-1-2 with one, one and two smooth setae, respectively.

P1-P4 (Fig. 4A-D). P1-P3 with two-segmented Exp and Enp; P4 with two-segmented Exp and one-segmented Enp. Armature formula (seta in Arabic numerals and spine in Roman numerals from outer-inner or outer-apical-inner margins) as follows: 


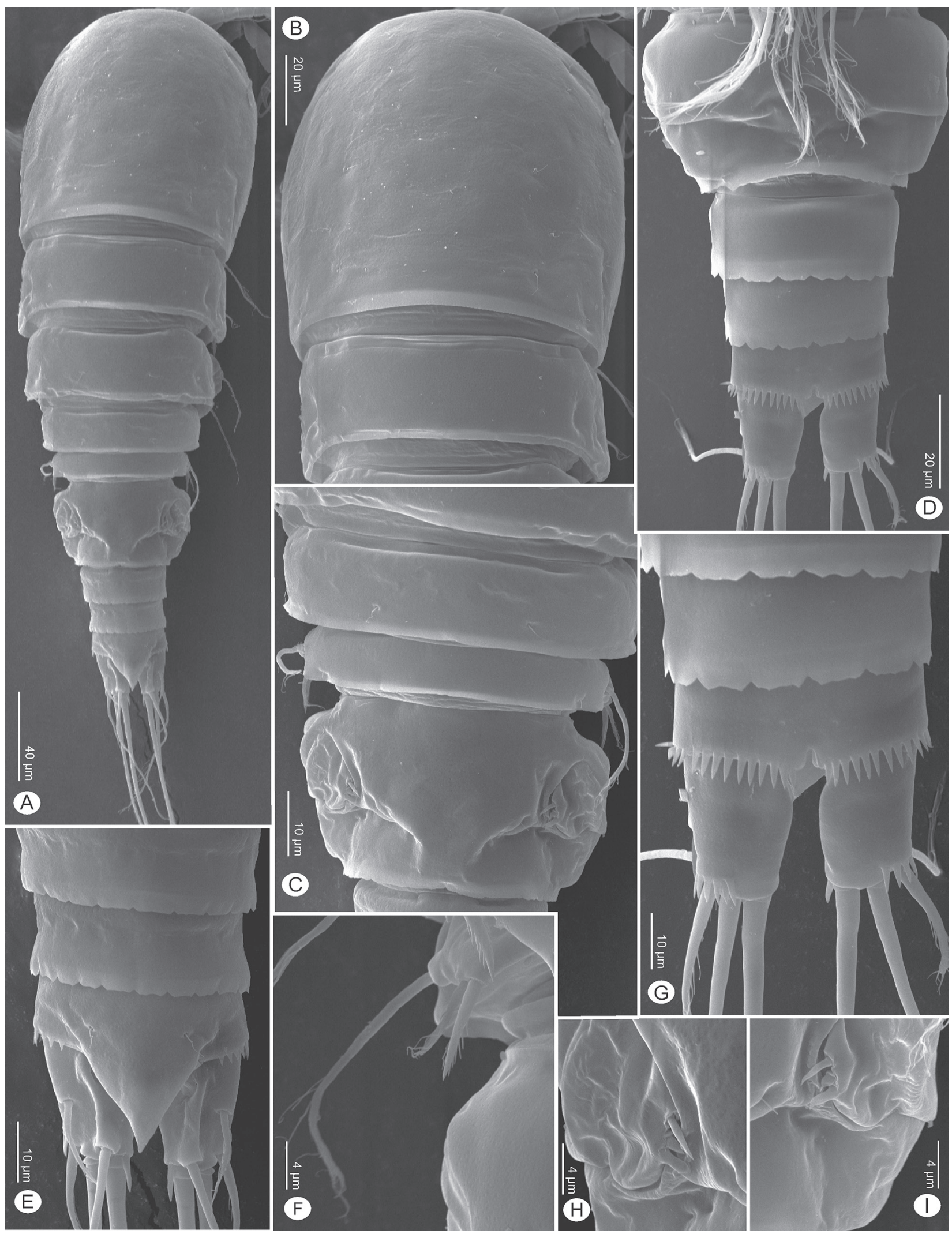

Figure 2. Bryocyclops jayabhumi sp. nov., SEM photographs of adult female: A. Habitus, dorsal view; B. Cephalothorax and pediger 2, dorsal view; C. Pediger 4-5 and genital double-somite, dorsal view; D. Urosome (without pediger 5), ventral view; E. Urosome 3-5 and caudal rami, dorsal view; F. P5 on pediger 5, dorsal view; G. Urosome 4-5 and caudal rami, ventral view; H-I. Left and right P6 on genital double-somite, dorsal view. 


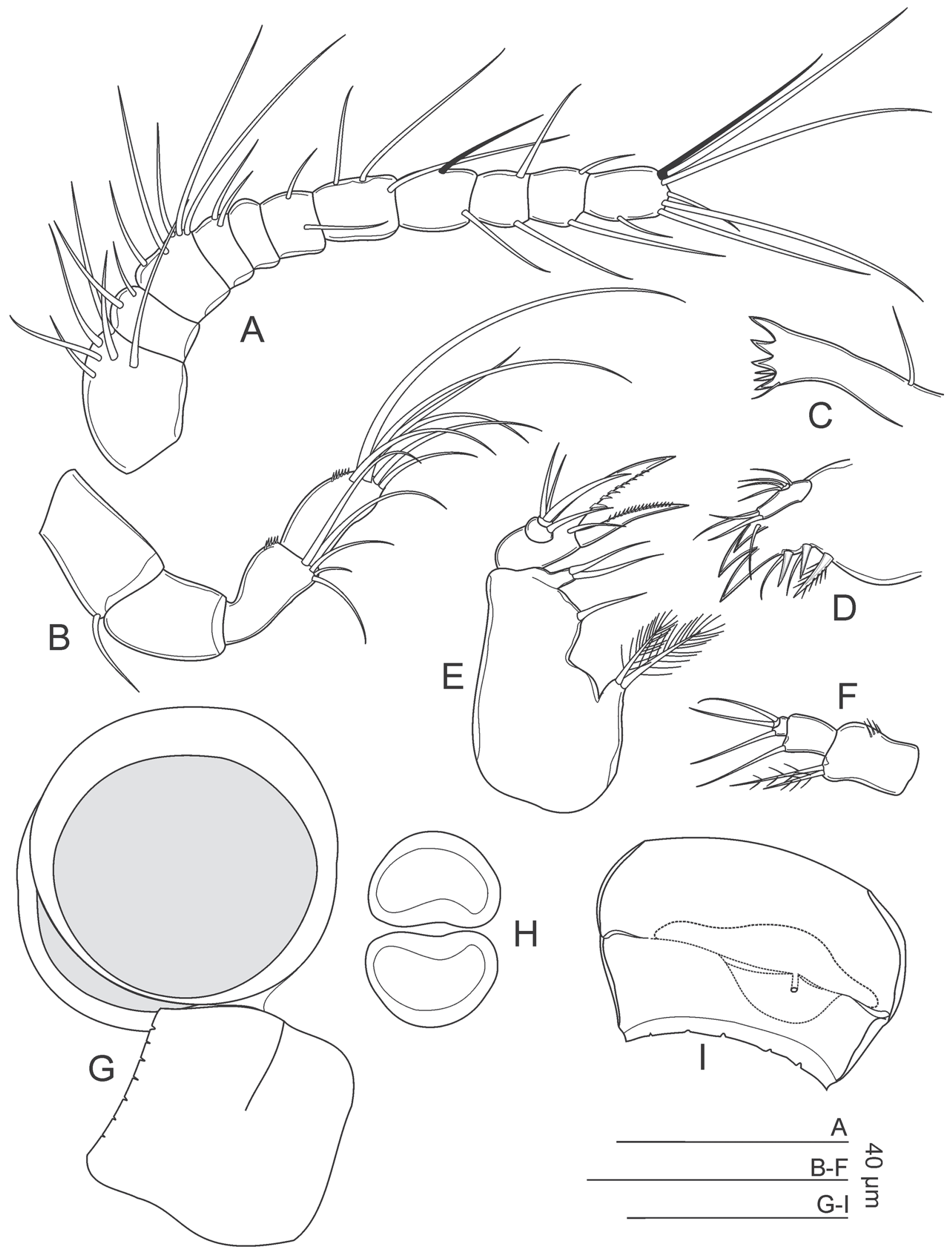

Figure 3. Bryocyclops jayabhumi sp. nov., adult female: A. Antennule; B. Antenna; C. Mandible; D. Maxillule; E. Maxilla; F. Maxilliped; G. Egg sacs on genital double-somite; H. Pair of spermatophore; I. Genital double-somite, ventral view. 


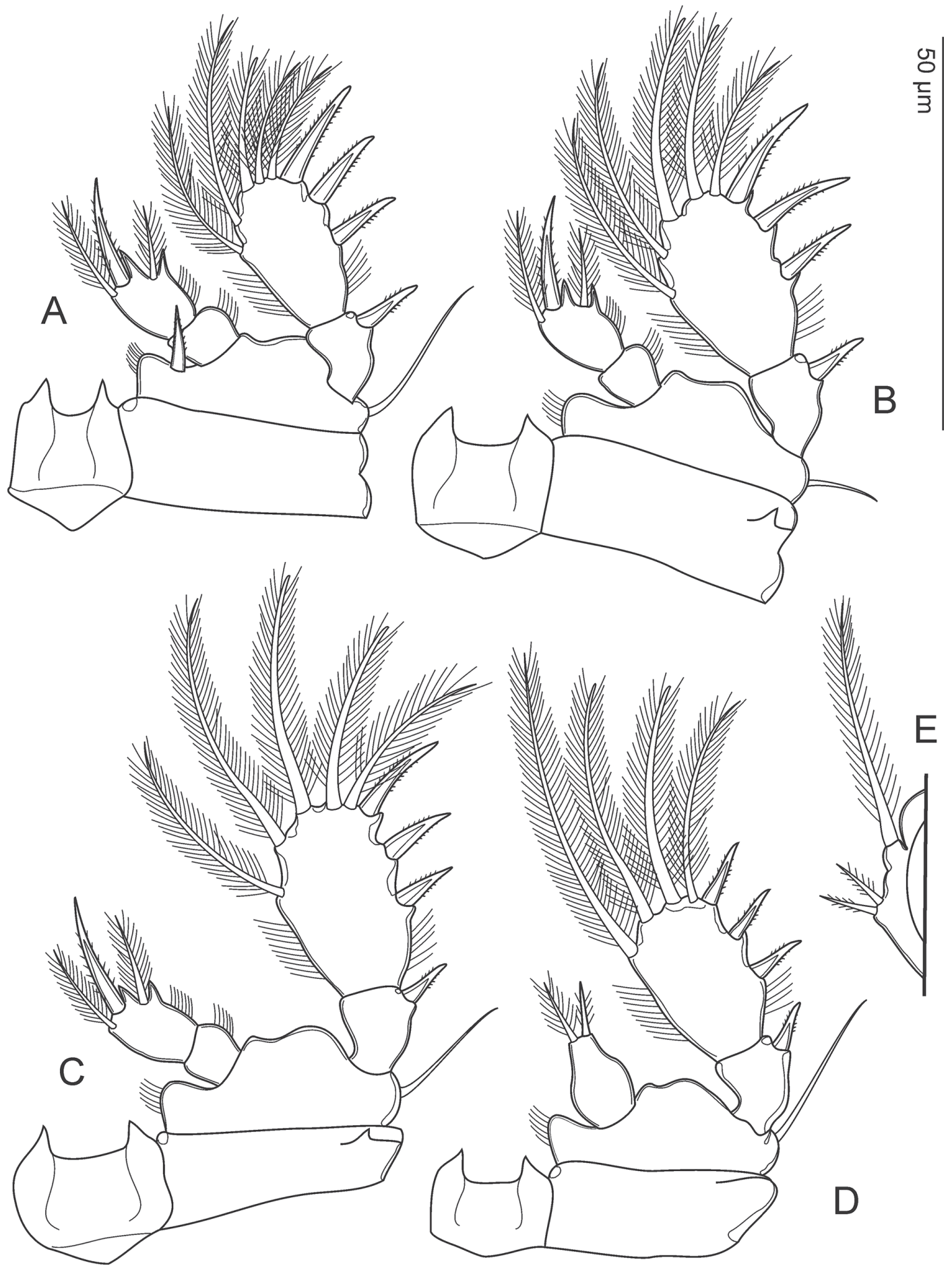

Figure 4. Bryocyclops jayabhumi sp. nov., adult female: A. P1; B. P2; C. P3; D. P4; E. P5.

$\begin{array}{lcccc} & \text { Coxa } & \text { Basis } & \text { Exp } & \text { Enp } \\ \text { P1 } & 0-0 & 1-\mathrm{I} & \text { I-0; III-2-3 } & 0-0 ; 1-\mathrm{I}+1-0 \\ \text { P2 } & 0-0 & 1-0 & \text { I-0; III-2-3 } & 0-0 ; 1-\mathrm{I}+1-0 \\ \text { P3 } & 0-0 & 1-0 & \text { I-0; III-2-3 } & 0-0 ; 1-\mathrm{I}+1-0 \\ \text { P4 } & 0-0 & 1-0 & \text { I-0; III-2-2 } & 0-\mathrm{I}+1-0\end{array}$

P1 (Fig. 4A). Intercoxal sclerite with acute distal margins. Coxa without inner seta. Basis with bare, slender outer seta and robust inner spine; setules on inner distal corner. Exp-1 with outer spine. Exp-2 with three spines on outer margin; two apical setae; blunt seta and two normal setae on inner margin. Enp-1 without seta on inner margin. Enp-2 with apical seta and spine; additional seta on outer margin.

P2-P3 (Fig. 4B, C). Intercoxal sclerite, coxa, basis similar to $\mathrm{P} 1$, but basis without inner spine. Exp-1 with outer spine. Exp-2 with three outer spines, apical normal seta and blunt seta, inner blunt seta and two normal setae. Enp-1 without inner seta. Enp-2 with apical seta and spine; additional seta on the outer margin.

P4 (Fig. 4D). Intercoxal sclerite with acute distal margins. Coxa without inner seta. Basis with slender outer seta. Two-segmented Exp. Exp-1 with outer spine. 
Exp-2 with three outer spines, apical normal seta and blunt seta, inner blunt seta and normal seta. One-segmented Enp, oval; with two apical pinnate setae, both shorter than segment.

P5 (Figs 2F, 4E). Completely fused to somite ventrolaterally, with one long and two short pinnate setae. Proximal (dorsal) seta arising from lateral prominence; slender, longer than 4.0 times of the remaining setae; distal (ventral) setae strong, subequal in length.

P6 (Fig. 2H, I). Reduced to semi-circular plate, with three short elements: anterior seta articulated, two poste- rior setae fused to plate. Posterior seta as long as anterior one. Middle seta spiniform, shortest.

Egg sac (Fig. 3G). Two large eggs attached ventrally to segment, with an average egg diameter of $60 \mu \mathrm{m}$.

Spermatophore (Fig. 3H). The spermatophores are generally bean-shaped.

Adult male. Body length (Fig. 5A), excluding caudal rami, 320-335 $\mu \mathrm{m}$ (mean $330 \mu \mathrm{m}, \mathrm{n}=5$ ); smaller than female. General segmentation and ornamentation (Fig. 5A-D) similar to female. Genital somite and urosomite 3 not fused as in female, 1.8 times as long as

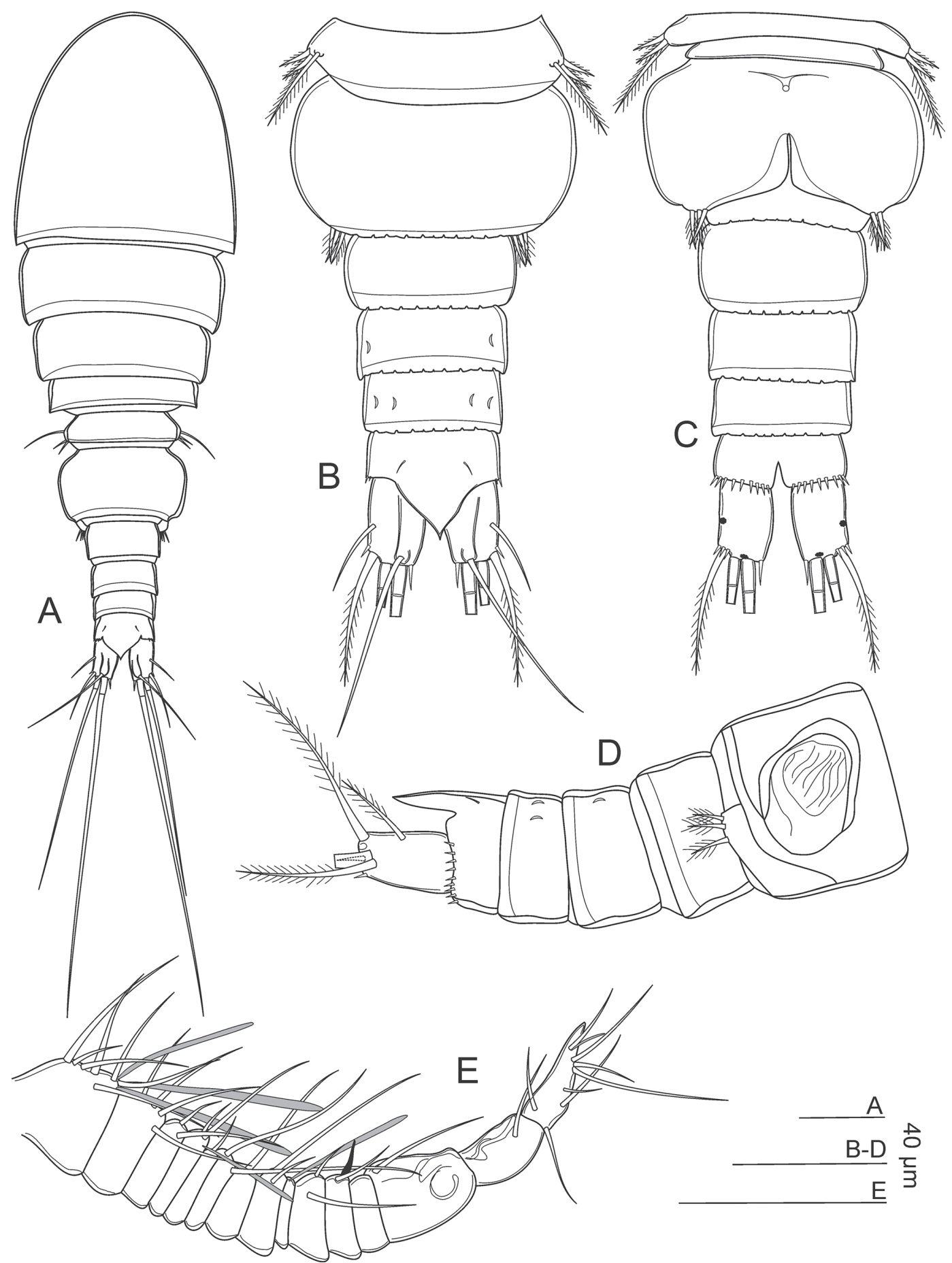

Figure 5. Bryocyclops jayabhumi sp. nov., adult male: A. Habitus, dorsal view; B. Urosome, dorsal view; C. Urosome, ventral view; D. Urosome (without pediger 5), lateral view; E. Antennule. 
wide $(n=5)$. Anal operculum (Fig. 5B, D) as in female, but shorter.

Antennule (Fig. 5E). Fifteen-segmented, geniculate. Armature formula as follows: 7+3A.4.2.2+A. 1.2.1.2.A.2.1+Sp.0.1.1.8+A.

Antenna, mouthparts, P1 (Fig. 6A) and P5 similar to those in female. Sexual dimorphism is observed on P2P4 and P6 as follows:

P2 (Fig. 6B). Intercoxal sclerite with acute distal margins. Coxa without inner seta. Basis with bare, slender outer seta; setules on inner distal corner. Two-segmented Exp, Exp-1 with outer spine. Exp-2 with three outer spines, apical normal seta and blunt seta, inner blunt seta and two normal setae. Two-segmented Enp, Enp-1 without inner seta. Enp-2 with one spine and three pinnate setae (inner, apical and outer setae).

P3 (Fig. 6C). Intercoxal sclerite, coxa, basis, Exp similar to P2. with outer spine. Enp-1 without inner seta. Enp-2 with one transformed spine and two pinnate setae (apical and outer setae). Apical transformed spine with hook-like tip bent outwards, medial part slightly swollen, smooth.

P4 (Fig. 6D). Intercoxal sclerite with acute distal margins. Coxa without inner seta. Basis with slender outer seta. Two-segmented Exp. Exp-1 with outer spine. Exp-2 with three outer spines, two apical and two inner normal setae. Two-segmented Enp. Enp-1 without inner seta. Enp-2 with two apical pinnate setae.
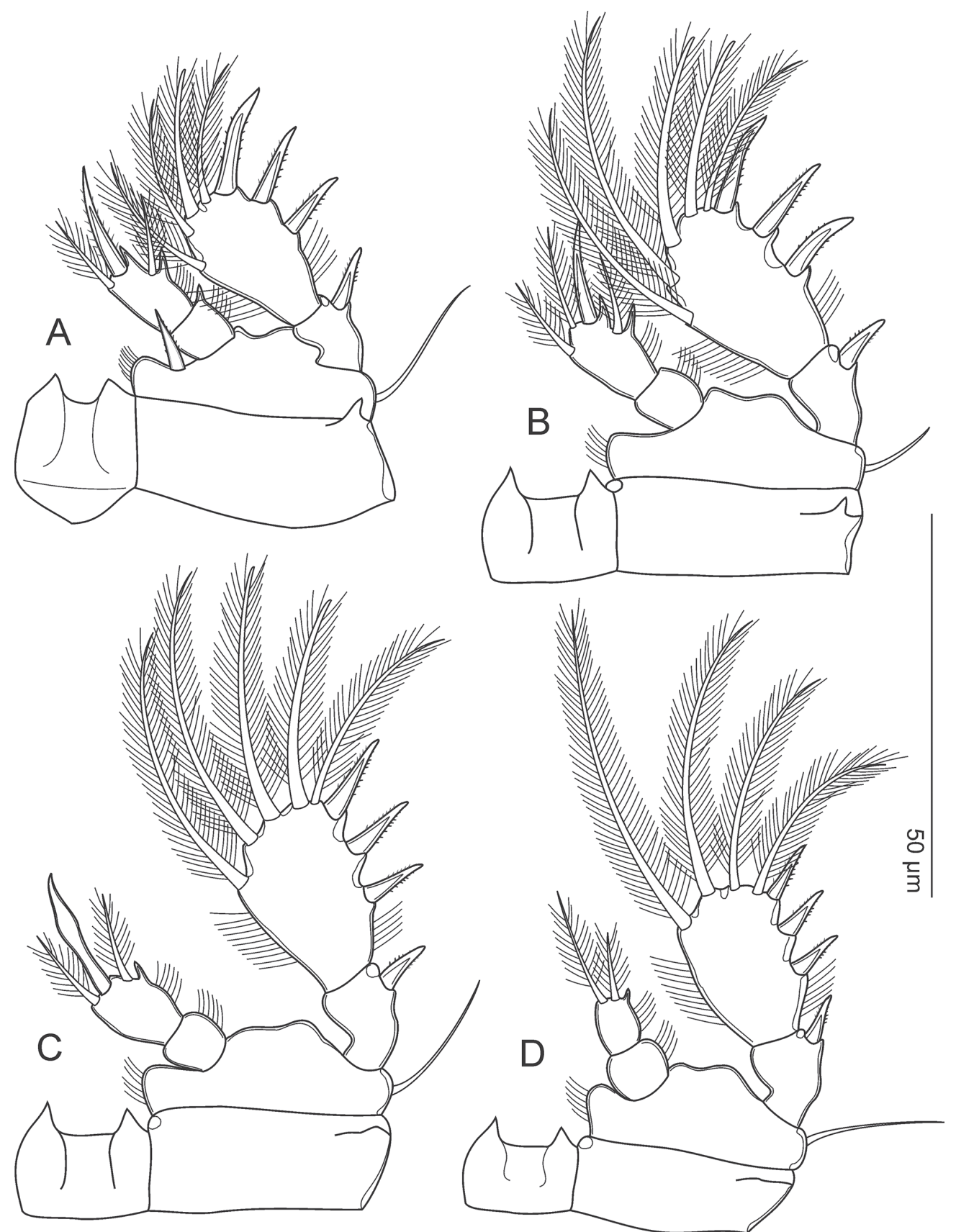

Figure 6. Bryocyclops jayabhumi sp. nov., adult male: A. P1; B. P2; C. P3; D. P4. 
P6 (Fig. 5B-D). Reduced to simple plate, represented by three subequal pinnate setae.

Differential diagnosis. Bryocyclops jayabhumi sp. nov. can be assigned to the genus Bryocyclops s. str. as it exhibits the following characteristics: i) P5 completely fused to somite, with three elements inserted directly on the thoracic somite; ii) P1-P4 with two-segmented Exp and Enp, except female P4 with one-segmented Enp; iii) P1-P4 intercoxal sclerites with acute free distal margins; iv) P1-P4 Exp-2 with spine and setal formula 3.3.3.3 and 5.5.5.4, respectively; and v) sexual dimorphisms on P3-P4, with transformed spine on male P3 Enp-2. The new species, therefore, fits into Group VII sensu Watiroyram et al. (2015), because it has two elements on the P4 Enp and P1 coxa without inner seta.

Group VII contains two species collected from Thailand - B. jayabhumi sp. nov. and B. maholarnensis Watiroyram, Brancelj \& Sanoamuang, 2015. Both species are obviously different from other species due to their P4 Enp, which terminates in two elements instead of five elements (when one-segmented) or four elements (when two-segmented). These species could, however, be differentiated from each other by the following characteristics: i) posterior margin of urosomites serrated (smooth in B. maholarnensis); ii) anal operculum triangular with acute-tip (round in B. maholarnensis); iii) inner setae on medial margin of P1-P4 Enp-1 absent (present in B. maholarnensis); iv) armature on female P2-P3 (each with three elements in the new species, versus four and two elements, respectively, in B. maholarnensis); v) armature on female P4 Enp (two apical elements in the new species versus one apical and one inner seta in B. maholarnensis). The male P3 Enp-2 of the new species has a well-developed, transformed spine similar to those in B. maholarnensis, but with a swollen medial portion.

The new species shows two remarkable characteristics on its swimming legs and in the urosomal serration in both sexes, which have never been seen in other examples of Bryocyclops s. str. The new species lacks inner distal setae on P1-P4 Enp-1 and has a different serrated pattern on urosomites $1-4$. The posterior margin on the somites of its congeners have normal serration, with lobes on free margin of hyaline fringe (for example, B. anninae (Menzel, 1926); B. asetus Watiroyram, 2018; B. maewaensis Watiroyram, Brancelj \& Sanoamuang, 2012; B. muscicola (Menzel, 1926); B. muscicoloides Watiroyram, 2018; B. trangensis Watiroyram, 2018), versus the new species, which has sparsely indented and a completely smooth hyaline fringe in B. maholarnensis.

Ecology and distribution. The new species has been found in only one locality, about $140 \mathrm{~km}$ away from its most similar species (B. maholarnensis). Bryocyclops jayabhumi sp. nov. is so far confined to this locality, while B. maholarnensis has a wide distribution range across Loei and Nong Bua Lam Phu Provinces. Although the salinity of water containing B. jayabhumi sp. nov. was not measured, it is evidently a freshwater species, as its locality is $573 \mathrm{~m}$ above sea level and approximately $450 \mathrm{~km}$ from the nearest sea. The sampling site, Prakai Phet Cave, is not connected to running water or other groundwater; it is only fed water from the stalactites and tree roots penetrating its ceiling (Fig. 1C). No other copepods were found during the study period.

\section{Discussion}

The genus Bryocyclops Kiefer, 1927 is polyphyletic. Variable characteristics determine species in this genus and, as it contains such a complex array of species, it will likely be divided into distinct genera (Dussart and Defaye 2006; Fiers and Van Damme 2017). The diagnostic characteristics for Bryocyclops are incompletely defined because there are deficiencies in the descriptions of most species, especially their antennae, mouthparts, first three swimming legs, integument ornamentations and genital fields. Different authors use different criteria to characterise the genus - except for the male P3 Enp-2, which is uniformly described as having an apical transformed spine, as well as the P4 coxa, which has no inner seta (Rocha and Bjornberg 1987).

\section{The original generic affinities}

Kiefer (1927) separated three Java species from the genus Cyclops Müller O.F., 1785: C. anninae Menzel, 1926; C. bogoriensis Menzel, 1926; and C. muscicola Menzel, 1926. From these, he erected the genus Bryocyclops Kiefer, 1927, the species of which were characterised by P5 being completely fused to the thoracic somite, having three setae. Earlier species, described before 1937 and having this reduced P5, were considered members of Bryocyclops.

In 1937, Kiefer provided the additional four characteristics of the genus: 1) a genital segment that is wider than it is long, 2) a P4 coxa without inner seta, 3) a male P3 with a transformed spine and 4) an acute distal margin of the intercoxal sclerite of the legs (unspecified legs, but probably P1-P4).

Later, Lindberg (1953-1954) revised the genus and lumped all species into Bryocyclops s. lato by using the following characteristics: 1) reduced P5, 2) sexual dimorphism of P3-P4 (male P3 with/without a transformed spine), 3) P4 coxa without inner seta, 4) P1 basis with/ without inner spine, 5) round or acute distal margin of the intercoxal sclerite of $\mathrm{P} 4,6$ ) variable spine and setae formulae for P1-P4 Exp-2, 7) variable armature on P4 Enp, 8) male P6 with 2-3 elements and 9) bulging anterior receptaculum seminis, which is more developed than the posterior receptaculum seminis. At the same time, Lindberg also divided Bryocyclops s. lato. into six groups (Groups I-VI).

The diagnosis of the genus Bryocyclops s. lato, as well as the status of the groups comprised in it, has been much debated recently and its members have been separated into five genera: Bryocyclops s. str.; Haplocyclops Kiefer, 1952; Palaeocyclops Monchenko, 1972; Rybocyclops Dussart, 1982; and Thalamocyclops Fiers \& Van Damme, 2017. 
Although some authors believe that the Palaeocyclops genus should have remained the subgenus Bryocyclops (Palaeocyclops) Monchenko, 1972, the status of the genus Palaeocyclops is indubitable when considering the possibility of convergences and the morphological differences (Fiers 2002; Dussart and Defaye 2006; Ranga Reddy and Defaye 2008; Fiers and Van Damme 2017).

\section{Remarks on some generic characteristics}

Members of Bryocyclops s. str. have acute intercoxal sclerites on their free distal margins, at least on P4. The swimming legs of many early known species (before 1972) are incompletely illustrated and described, except for P4. Regarding the available information, all species of Groups III-VI are characterised by round distal margins in all legs (P1-P4) versus the acute forms on P4 in Groups I, II and VII. In addition, amongst Groups I, II and VII, the anterior legs tend to have rounder distal margins compared to the posterior legs. For example, $\mathrm{P} 1$ is round in the females of B. anninae (Menzel, 1926) and B. asetus Watiroyram, 2018 (Watiroyram 2018a; Sanoamuang et al. 2019).

The presence of an inner coxal seta is also, so far, unified for the system of cyclopine genera (Reid and Spooner 1998). This seta and a medial spine at the basis are present on P1, but lacking on other legs in all known Bryocyclops s. str. species and both of these characteristics are identical in the Bryocyclops s. str., Palaeocyclops and Thalamocyclops genera. However, the inner coxal seta is absent on the P1 of some Bryocyclops species, such as B. absalomi Por, 1981, B. asetus, B. maholarnensis and B. jayabhumi sp. nov. Thus, the presence of the inner coxal seta on P1 is a non-significant characteristic for generic diagnosis of Bryocyclops s. str.

All Bryocyclops s. str. species exhibit specialised sexual dimorphism on P3 and P4, which other cyclopids usually express only on the urosomal segmentation, antennules, P5 and P6 (Fiers 2002). Rocha and Bjornberg (1987) note that the transformed spine of the male P3 Enp-2 is traditionally used to determine genus because it is present amongst all Bryocyclops s. str. Additionally, the discovery of new species has confirmed that the apical spine of the male P3 Enp-2 varies in the degree of transformation (its tip, position and ornamentation of medial swelling). For example, B. maewaensis has the greatest medial swelling at the distal half of the spine, produced in the outer margin, similar to most of its congeners; B. jayabhumi sp. nov. has less medial swelling at about one-half of the spine length and is enlarged in both margins; and B. maholarnensis presents the lowest level of transformation. These three species have no ornamentation (spinules) on the surface of their expended parts, but these spinules are present in B. asetus, B. muscicola, B. muscicoloides and B. trangensis. This transformed spine on the male P3 Enp-2 has also been reported in the Thalamocyclops, Palaeocyclops and Siamcyclops genera
(Monchenko 1972; Fiers and Van Damme 2017; Boonyanusith et al. 2018). This characteristic has traditionally been used to recognise Bryocyclops and to reasonably conclude that the genera Thalamocyclops, Palaeocyclops and Siamcyclops are more closely related to Bryocyclops s. str. than are Haplocyclops and Rybocyclops. Reid and Spooner (1998) propose that the female P4 Enp of Bryocyclops, which has five elements in most previously-described species (e.g. B. bogoriensis, B. campaneri, B. caroli, B. muscicola, B. muscicoloides, B. trangensis etc.) is considered plesiomorphic. Thus, the presence of two instead of five elements on the P4 Enp in B. maholarnensis and B. jayabhumi sp. nov. (Group VII) is probably apomorphic and new to the genus.

The male P6 of the new species and of all Bryocyclops s. str. (except B. africanus, Group III) and Thalamocyclops species, has three setae. These are considered to be plesiomorphic formations in cyclopines, which have been reduced to two setae in closely-related genera, including Palaeocyclops, Rybocyclops and Haplocyclops. The female P6 of Bryocyclops s. str. and Thalamocyclops are also similar, but they show more reduction than the male forms; the P6 vestiges have three elements in spiniform and setiform, but they always appear in Haplocyclops and Rybocyclops with setae (unknown amongst Palaeocyclops). Amongst seven species collected in Thailand, the P6 of B. trangensis is most similar to Thalamocyclops (but B. trangensis and other Bryocyclops are easily distinguished from Thalamocyclops by the structure of P5), having two setae and one spinule, versus six other species armed with one seta and two spinules ( $B$. jayabhumi sp. nov. with shorter and stronger setae than $B$. asetus, B. maewaensis, B. maholarnensis, B. muscicola and B. muscicoloides).

The new species, depicted in this study, is ornamented with refractile points or pits on the body surface, which is another characteristic presented mostly in Bryocyclops s. str., except for B. asetus (Watiroyram 2018a). Although the possession of refractile points is not confined only to Bryocyclops, it is useful for separating Bryocyclops species from those in closely-related genera, which lack this ornamentation (J. Reid, personal communication), including Rybocyclops (=B. pauliani), Haplocyclops (= B. correctus, B. neuter) and Thalamocyclops (= B. soqotraensis) (Reid 1999; Fiers 2002; Fiers and Van Damme 2017; Watiroyram 2018b). Actually, this characteristic is either present or absent amongst copepod species of the same genus in both harpacticoid and cyclopoid copepods, especially those living in groundwater, such as Halicyclops Norman, 1903 (H. maculatus Rocha \& Hakenkamp, 1993, from wells); Speocyclops Kiefer, 1937 (S. orcinus Kiefer, 1937, from caves); Elaphoidella Chappuis, 1929 (E. bromeliaecola (Chappuis, 1928), from caves and phytotelmata); Moraria T. \& A. Scott 1893 (M. affinis Chappuis, 1927, from moss; M. cristata Chappuis, 1929, from caves; and M. laurentica Willey, 1927, from litter) (Rocha and Hakenkamp 1993; Fiers and Moldovan 2012; Watiroyram 2018a). The posses- 
sion of refraction points is also probably associated with weak swimmers in groundwater, scleractinian and parasitic, rather than true planktons; it may also depend on the species lineage, rather than on convergent evolution forced from dependency in the same habitats. This idea is supported by the presence of two cyclopines in the same cave from Vietnam: Pseudograeteriella longiaesthetascus Sanoamuang, Boonyanusith \& Brancelj, 2019, which does not have this characteristic and Bryocyclops anninae, which possesses the characteristic and has been found outside the cave in phytothelmata and wet moss. This characteristic is also lacking in the other stygobitic copepods recently reported in various Thailand caves: Boholina laorsriae Boonyanusith, Wongkamhaeng \& Athibai, 2020; Fierscyclops tanaosriensis Boonyanusith, Brancelj \& Sanoamuang, 2013; F. solaris Boonyanusith, Brancelj \& Sanoamuang, 2013; Metacyclops thailandicus Boonyanusith, Sanoamuang \& Brancelj, 2018; and Siamcyclops cavernicolus Boonyanusith, Sanoamuang \& Brancelj, 2018. Likewise, the blunt or obtuse setae on P2-P3 Exp-2 (and, rarely, on P1) were always present in the early observations of Bryocyclops s. str. compared to other cyclopines (Reid 1999; Sanoamuang et al. 2019). However, the Bryocyclops species collected recently in Thailand differ from previous reports in that B. asetus, $B$. muscicoloides and B. trangensis lack blunt setae (Watiroyram 2018a, b).

The receptaculum seminis is also useful for determining species and genera in the Bryocyclops s. lato. Although this characteristic is still unknown for many precise species, it seems that Bryocyclops species have a developed anterior part of the receptaculum seminis, as do Haplocyclops, Thalamocyclops species: B. anninae; B. caroli Bjornberg, 1985; B. campaneri Rocha \& Bjornberg, 1987; and B. jayabhumi sp. nov. (Fiers and Van Damme 2017; Sanoamuang et al. 2019; the present study). On the contrary, both the anterior and posterior portions of this structure are developed in Palaeocyclops and Rybocyclops species (Dussart and Defaye 2001; Ranga Reddy and Defaye 2008). The shape of the spermatophore has, therefore, been used as a generic characteristic to differentiate Siamcyclops from Bryocyclops s. str. Siamcyclops have L-shaped spermatophore structures versus the kidney or bean-shaped spermatophore structures found in most Bryocyclops species (Boonyanusith et al. 2018). However, this characteristic does not fit B. trangensis and B. asetus, which present two other shapes (see Watiroyram 2018a, fig. 3C; Watiroyram 2018 b, figs $8 C$, 9A). It seems, therefore, that the spermatophore structure takes a unique form in Bryocyclops s. str. and, thus, it must be re-observed amongst the earlier discovered species, whose descriptions are lacking this information. The shapes of spermatophore structures vary more amongst cyclopoids than do those in harpacticoids and calanoids, which are generally cylindrical (Williamson and Reid 2009); in this way, spermatophore shapes may be used to determine what species belong to the Bryocyclops s. str. genus.

\section{Conclusion}

Bryocyclops jayabhumi sp. nov. is undoubtedly a new species of Bryocyclops s. str. It shares common characteristics with Group VII, showing sexual dimorphism on P3-P4 and the armature of $\mathrm{P} 4$. The new species is easily distinguished from its congeners by lacking an inner seta on the Enp1 of P1-P4. This study asserts that the characteristics of Group VII, sensu Watiroyram et al. (2015) may, therefore, be amended from 'the male P3 Enp-2 without a transformed spine' to 'the male P3 Enp-2 with a transformed spine'. Based on the available information concerning the common characteristics in all described species, a generic emendation of Bryocyclops s. str. is proposed as follows: i) 11-segmented antennule in female; ii) well developed anal operculum; iii) genital-double somite with length/width ratio less than 1 ; iv) $\mathrm{P} 1-\mathrm{P} 4$ with two-segmented rami or one-segmented rami; v) P1 basis with inner spine; vi) male P3 Enp-2 with an apical transformed spine; vii) P4 intercoxal plate with acute distal margins; viii) $\mathrm{P} 4$ coxa without inner seta; ix) spine and setal formula for P1-P4 Exp-2 being 3.3.3.3 and 5.5.5.4, respectively; $\mathrm{x}$ ) P5 with three elements and without segment; and xi) male P6 with three elements. According to this view, the genus Bryocyclops $\mathrm{s}$. str. contains currently 21 species. Excluded species are as follows: B. constrictus Lindberg, 1947; B. travancoricus Lindberg, 1947; and B. africanus Kiefer, 1932.

\section{Acknowledgements}

This study was supported by the National Research Council of Thailand (Grant No. 256108A1340006) and the Thailand Research Fund (TRF: Grant No. MRG62A13402007). I wish to thank Dr Janet W. Reid for her help in generic confirmation and the critical suggestions. The author would like to thank the inputs of Dr Anton Brancelj as reviewer and Dr Kay Van Damme as subject editor of Zoosystematics and Evolution for their valuable comments and suggestions towards improving the manuscript.

\section{References}

Bjornberg MHGC (1985) Bryocyclops caroli sp. n. (Crustacea, Copepoda, Cyclopoida), the first representative of the genus in South America. Hydrobiologia 124: 237-241. https://doi.org/10.1007/BF00015240

Boonyanusith C, Brancelj A, Sanoamuang L (2013) First representatives of the genus Fierscyclops Karanovic, 2004 (Copepoda, Cyclopidae) from South East Asia. Journal of Limnology 72(s2): 275-289. https://doi.org/10.4081/jlimnol.2013.s2.e13

Boonyanusith C, Sanoamuang L, Brancelj A (2018) A new genus and two new species of cave-dwelling cyclopoids (Crustacea, Copepoda) from the epikarst zone of Thailand and up-to-date keys to genera and subgenera of the Bryocyclops and Microcyclops groups. European Journal of Taxonomy 431: 1-30. https://doi.org/10.5852/ejt.2018.431

Boonyanusith C, Wongkamhaeng K, Athibai S (2020) A new species of Boholina (Crustacea, Copepoda, Calanoida) and a first record for 
stygobiotic calanoid fauna from a cave in Thailand. Zookeys 904: 1-22. https://doi.org/10.3897/zookeys.904.37609

Brancelj A, Watiroyram S, Sanoamuang L (2010) The first record of cave-dwelling Copepoda from Thailand and description of a new species: Elaphoidella namnaoensis n. sp. (Copepoda, Harpacticoida). Crustaceana 83(7): 779-793. https://doi. org/10.1163/001121610X502894

Chappuis PA (1928) Neue Harpacticiden aus Java. Treubia 10: 271-283.

Daday E (1901) Mikroskopische süsswasserthiere aus Deutsch Neu Guinea. Természetrajzi Fü zetek, Budapest 24: 1-56.

Dussart B, Defaye D (2006) World directory of Crustacea Copepoda of inland waters II-Cyclopiformes. Backhuys Publishers, Leiden, $354 \mathrm{pp}$.

Ellis M, Pauwels OSG (2012) The bent-toed geckos (Cyrtodactylus) of the caves and karst of Thailand. Cave and Karst Science 39(1): $16-22$.

Ferrari F, Dojiri M (1987) The calanoid copepod Euchaeta antarctica from southern ocean Atlantic Sector midwater trawls, with observations on spermatophore dimorphism. Journal of Crustacean Biology 7(3): 458-480. https://doi.org/10.2307/1548295

Fiers F (2002) The genus Haplocyclops Kiefer, 1952 (Copepoda, Cyclopoida, Cyclopidae): redescription of the type-species, $H$. gudrunae, and its congeners. Hydrobiologia 474: 155-169. https:// doi.org/10.1023/A:1016579619924

Fiers F (2012) The generic concept of Allocyclops Kiefer, 1932 (Copepoda: Cyclopoida: Cyclopidae): an alternative view. Journal of Natural History 46: 175-247. https://doi.org/10.1080/00222933.20 11.626530

Fiers F, Moldovan OT (2012) The north American continental copepods in Chappuis' legacy and redescription of three species of the genus Moraria T. \& A. Scott 1893 (Crustacea: Copepoda: Harpacticoida). Zoological Studies 51(8): 1549-1573.

Fiers F, van Damme K (2017) Thalamocyclops pachypes gen. nov., sp. nov. (Copepoda: Cyclopoida: Cyclopidae), a crevicular cyclopine from Socotra Island (Yemen): tale of a remarkable survival drive. Journal of Natural History 51(41-42): 2463-2507. https://doi.org/1 $0.1080 / 00222933.2017 .1344328$

Filoux A, Lespes C, Wattanapituksakul A, Thongcharoenchaikit C (2014) Note about new Pleistocene faunal remains from Tham Prakai Phet, Chaiyaphum Province, Thailand. Journal of Science and Technology Mahasarakham University 33(4): 378-385. https:// doi.org/10.14456/jscitech.2014.69

Huys R, Boxshall GA (1991) Copepod evolution. The Ray Society, London, $468 \mathrm{pp}$.

Kiefer F (1927) Versuch eines systems der Cyclopiden. Zoologischer Anzeiger 73: 302-308.

Kiefer F (1928) Beiträge zur copepodenkunde (IX). Zoologischer Anzeiger 76: 99-102.

Kiefer F (1932) Neue Diaptomiden und Cyclopiden aus Franzosisch-Westafrika (Vorlaufige Mitteilungen). Buletinul Societatii di Stiinte din Cluj (Romania) 6: 523-528.

Kiefer F (1935) Neue susswasser cyclopiden (Crustacea Copepoda) aus ostafrika. Bulletin de la Societe des Sciences de Cluj (Roumanie) 7: 237-242.

Kiefer F (1952) Haplocyclops gudrunae n. g. et n. sp., ein neuer RudcrfuBkrebs (Crustacea Copepoda) aus Madagaskar. Zoologischer Anzeiger 149: 240-243.

Kiefer F (1956) Recherches sur la faune interstitielle des sédiments marins et d'eau douce à Madagascar. VI Cyclopoides de Madagascar
(Crustacea Copepoda). Mémoires de L' Institut Scientifique de Madagascar, sér. A, 10: 43-68.

Kiefer F (1960) Zwei neue cyclopiden (Crust. Cop.) als bewöhner des sandlückensystems im niger (Französischer Sudan). Bulletin de l'Institut Français d'Afrique Noire 22: 395-401.

Lindberg K (1947) Cyclopïdes (Crustacés Copépodes) nouveaux de l'Inde. Records of the Indian Museum 45(1): 47-55.

Lindberg K (1953) Les cyclopides (Crustacés Copépodes) très évolués en tant que habitants des eaux souterraines. Actes Premier Congrès International de Spéléologie 3: 71-83.

Lindberg K (1954) Cyclopides (Crustacés copépodes) d'îles du Pacifique Sud (Mélanésie et Micronésie) et de Bornéo. Kungl. Fysiografiska Sällskapets I Lund Förhandlingar 24(18): 1-14.

Menzel R (1926) Cyclopides muscicoles et bromélicoles de Java (Indes Néerlandaises). Annales de Biologie Lacustre 14: 209-216.

Monchenko VI (1972) Tsiklopy (Copepoda, Cyclopodae) gruntovykh vod pustyni Kyzylkum. Trudy Zoologicheskogo Instituta 51: 78-97.

Pauwels OSG, Sumontha M, Keeratikiat K, Phanamphon E (2014) Cyrtodactylus kunyai (Squamata: Gekkonidae), a new cave-dwelling Bent-toed Gecko from Loei Province, northeastern Thailand. Zootaxa 3821(2): 253-264. https://doi.org/10.11646/zootaxa.3821.2.5

Por FD (1981) A new species of Bryocyclops (Copepoda: Cyclopoida) and of Parastenocaris (Copepoda: Harpacticoida) from a cave in Israel and some comments on the origin of the cavernicolous copepods. Israel Journal of Zoology 30: 35-46.

Rafinesque CS (1815) Analyse de la Nature ou Tableau de l'Univers et des Corps organises. Imp. Jean Barravecchia, Palermo, 224 pp. https://doi.org/10.5962/bhl.title.106607

Ranga Reddy Y, Defaye D (2008) Discovery of the genus Rybocyclops Dussart, 1982 (Crustacea, Copepoda, Cyclopoida) in subterranean groundwaters of southeastern India, with the description of a new species and its biogeographic significance. Zootaxa 1810: 40-50. https://doi.org/10.11646/zootaxa.1810.1.2

Reid JW, Spooner JD (1998) Stolonicyclops heggiensis, new genus, new species, from Georgia, U.S.A. (Copepoda: Cyclopoida: Cyclopidae). Journal of Crustacean Biology 18(2): 405-411. https:// doi.org/10.2307/1549333

Reid JW (1999) New records of Bryocyclops from the continental U.S.A., Puerto Rico, and Brazil (Copepoda: Cyclopoida: Cyclopidae). Journal of Crustacean Biology 19(1): 84-92. https://doi. org/10.1163/193724099X00286

Rocha CEF, Bjornberg MHGC (1987) Copepods of the Juréia Ecological Reserve, state of São Paulo, Brazil. II. The genera Hesperocyclops, Muscocyclops, and Bryocyclops (Cyclopoida, Cyclopidae). Hydrobiologia 153: 97-107. https://doi.org/10.1007/BF00006642

Rocha CEF, Hakenkamp CC (1993) New species of Halicyclops (Copepoda Cyclopidae) from the United States of America. Hydrobiologia 259: 145-156. https://doi.org/10.1007/BF00006594

Sanoamuang L, Boonyanusith C, Brancelj A (2019) A new genus and new species of stygobitic copepod (Crustacea: Copepoda: Cyclopoida) from Thien Duong Cave in Central Vietnam, with a redescription of Bryocyclops anninae (Menzel, 1926). Raffles Bulletin of Zoology 67: 189-205. https://doi.org/10.26107/RBZ-2019-0016

Singtuen V, Won-In K (2018) Geodiversity and geoconservation of the Chaiyaphum region in Thailand for sustainable geotourism planning. GeoJournal of Tourism and Geosites 22(2): 548-560. https:// doi.org/10.30892/gtg.22223-310

Smith PFL, Stokes RB (1997) Geology and petroleum potential of the Khorat Plateau Basin in the Vientiane area of Lao 
P.D.R. Journal of Petroleum Geology 20(1): 27-50. https://doi. org/10.1111/j.1747-5457.1997.tb00754.x

Tanmuangpak K, Dumrongrojwattana P, Tumpeesuman C, Tumpeesuwan S (2015) Sinoennea loeiensis, a new species of diapherid microsnail (Pulmonata: Streptaxoidea: Diapheridae) from Phu Pha Lom Limestone Hill, Loei Province, northeastern Thailand. Raffles Bulletin of Zoology 63: 293-300.

Tran DL, Chang CY (2013) Graeteriella (Graeteriella) longifurcata, new species, a stygobitic cyclopoid species (Copepoda: $\mathrm{Cy}$ clopoida: Cyclopidae) from Central Vietnam. Proceedings of the Biological Society of Washington 126(3): 245-258. https://doi. org/10.2988/0006-324x-126.3.245

Tumpeesuwan C, Tumpeesuwan S (2014) Phuphanin costata, a new species of dyakiid land snail (Pulmonata: Dyakiidae) from Phu Pha Lom limestone area, Loei Province, northeastern Thailand. Raffles Bulletin of Zoology 62: 352-357.

Watiroyram S, Brancelj A, Sanoamuang L (2012) A new Bryocyclops Kiefer (Crustacea: Copepoda: Cyclopoida) from karstic caves in Thailand. Raffles Bulletin of Zoology 60 (1): 11-21.
Watiroyram S, Brancelj A, Sanoamuang L (2015) A new cave-dwelling copepod from northeastern Thailand (Cyclopoida: Cyclopidae). Raffles Bulletin of Zoology 63: 426-437.

Watiroyram S, Sanoamuang L, Brancelj A (2017) Two new species of Elaphoidella (Copepoda, Harpacticoida) from caves in southern Thailand and a key to the species of Southeast Asia. Zootaxa 4282(3): 501-525. https://doi.org/10.11646/zootaxa.4282.3.5

Watiroyram S (2018a) Bryocyclops asetus sp. n. and the presence of Bryocyclops muscicola (Menzel, 1926) from Thailand (Crustacea, Copepoda, Cyclopoida, Cyclopidae). Zookeys 793: 29-51. https:// doi.org/10.3897/zookeys.793.25005

Watiroyram S (2018b) Two new species of the genus Bryocyclops Kiefer, 1927 (Copepoda: Cyclopoida: Cyclopidae) from southern Thailand. Raffles Bulletin of Zoology 66: 149-169.

Williamson CE, Reid JW (2009) Copepoda. In: Likens GE (Ed.) Encyclopedia of Inland Waters, vol 3. Elsevier, Oxford, 633-642. https://doi.org/10.1016/B978-012370626-3.00146-0

Yeatman HC (1983) Copepods from microhabitats in Fiji, Western Samoa, and Tonga. Micronesica 19(1-2): 57-90. 